Eğitim Teknolojisi kuram ve uygulama Kış 2016 Cilt 6 Sayı 1

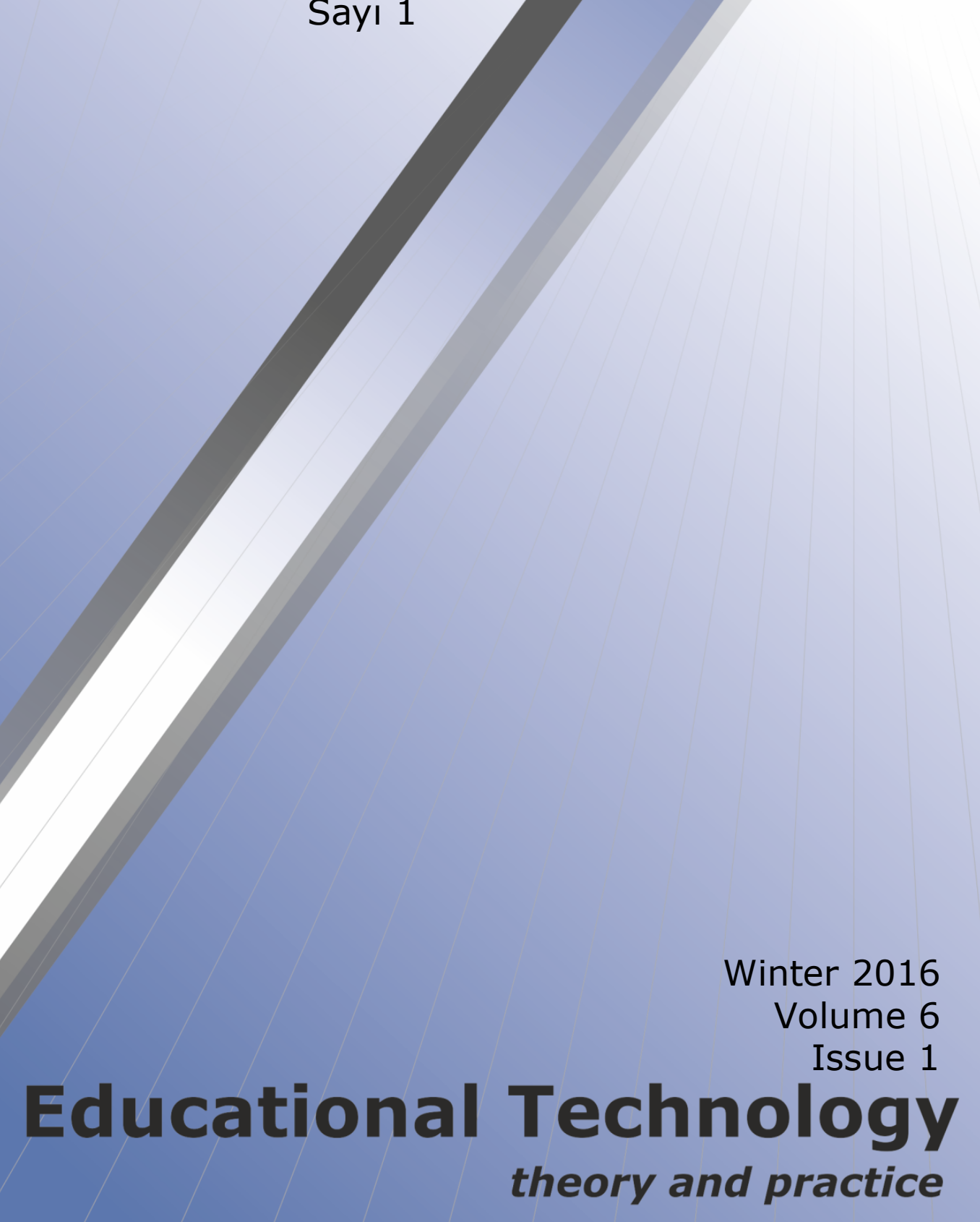


Cilt 6, Sayı 1, Kış 2016

Volume 6, Number 1, Winter 2016

Genel Yayın Editörü / Editor-in-Chief: Dr. Halil İbrahim YALIN Yardımcı Editör / Co-Editor: Dr. Tolga GÜYER

Sorumlu Yazı İşleri Müdürü / Publisher Editor: Dr. Sami ŞAHiN Redaksiyon / Redaction: Dr. Tolga GÜYER

Dizgi / Typographic: Dr. Tolga GÜYER

Sayfa Tasarımı / Page Design: Dr. Tolga GÜYER

Kapak Tasarımı / Cover Design: Dr. Bilal ATASOY

İletişim / Contact Person: Dr. Aslıhan KOCAMAN KAROĞLU

Taranmaktadır / Indexed in: ULAKBiM Sosyal ve Beşeri Bilimler Veritabanı, Türk Eğitim İndeksi, ASOS Sosyal Bilimler İndeksi

\section{Editör Kurulu / Editorial Board}

\begin{tabular}{l|l} 
& \\
Dr. Abdullah KUZU & Dr. Feza ORHAN \\
Dr. Akif ERGIN & Dr. H. Ferhan ODABAŞI \\
Dr. Ana Paula CORREIA & Dr. Hafize KESER \\
Dr. Aytekin IŞMAN & Dr. Halil Ibrahim YALIN \\
Dr. Buket AKKOYUNLU & Dr. Hyo-Jeong So \\
Dr. Cem ÇUHADAR & Dr. İbrahim GÖKDAŞ \\
Dr. Deniz DERYAKULU & Dr. Kyong Jee(KJ) KIM \\
Dr. Deepak SUBRAMONY & Dr. M. Oğuz KUTLU \\
Dr. Eralp H. ALTUN & Dr. M. Yaşar ÖZDEN
\end{tabular}

Dr. Abdullah KUZU

Dr. Akif ERGIN

Dr. Aytekin işMAN

Dr. Buket AKKOYUNLU

Dr. Eralp H. ALTUN
Dr. Mehmet GÜROL

Dr. Michael EVANS

Dr. Michael THOMAS

Dr. Özcan Erkan AKGÜN

Dr. Özgen KORKMAZ

Dr. S. Sadi SEFEROĞLU

Dr. Sandie WATERS

Dr. Scott WARREN

Dr. Servet BAYRAM
Dr. Şirin KARADENIZ

Dr. Tolga GÜYER

Dr. Trena PAULUS

Dr. Yasemin GÜLBAHAR GÜVEN

Dr. Yavuz AKPINAR

Dr. Yun-Jo AN

Dr. Adile Aşkım KURT
Dr. Agah Tuğrul KORUCU
Dr. Arif ALTUN
Dr. Aslıhan KOCAMAN
KAROĞLU
Dr. Ayfer ALPER
Dr. Aynur KOLBURAN GEÇER
Dr. Ayşegül BAKAR ÇÖREZ
Dr. Aytekin IŞMAN
Dr. Bilal ATASOY
Dr. Buket AKKOYUNLU
Dr. Cem ÇUHADAR
Dr. Deniz DERYAKULU
Dr. Ebru KILIÇ ÇAKMAK
Dr. Ebru SOLMAZ
Dr. Emin IBILI
Dr. Eralp H. ALTUN
Dr. Erinç KARATAŞ
Dr. Erhan GÜNEŞ

Dr. Erkan ÇALIŞKAN Dr. Erkan TEKINARSLAN

Dr. Ertan ZEREYAK

Dr. Ertuğrul USTA

Dr. F. Gizem KARAOĞLAN

Dr. Feza ORHAN

Dr. Fezile ÖZDAMLI

Dr. Filiz KALELIOĞLU

Dr. H. Ferhan ODABAŞI

Dr. Hafize KESER

Dr. Halil ERSOY

Dr. Halil Ibrahim YALIN

Dr. Hasan ÇAKIR

Dr. Işı KABAKÇI YURDAKUL

Dr. İbrahim GÖKDAŞ

Dr. Levent ÇELIK

Dr. M. Oğuz KUTLU

Dr. M. Yaşar ÖZDEN

Dr. Mehmet GÜROL
Dr. Mehmet Akif OCAK

Dr. Mukaddes ERDEM

Dr. Mustafa Serkan

GÜNBATAR

Dr. Mutlu Tahsin ÜSTÜNDAĞ

Dr. Nadire ÇAVUŞ

Dr. Necmi EŞGi

Dr. Nezih ÖNAL

Dr. Ömer Faruk URSAVAŞ

Dr. Ömür AKDEMIR

Dr. Özcan Erkan AKGÜN

Dr. Özgen KORKMAZ

Dr. Ramazan YILMAZ

Dr. Recep ÇAKIR

Dr. S. Sadi SEFEROĞLU

Dr. Sami ŞAHIN

Dr. Selay ARKÜN KOCADERE

Dr. Selçuk ÖZDEMIR

Dr. Semiral ÖNCÜ
Dr. Serdar ÇiFTÇi

Dr. Serçin KARATAŞ

Dr. Serpil YALÇINALP

Dr. Servet BAYRAM

Dr. Sibel SOMYÜREK

Dr. Şener BÜYÜKÖZTÜRK

Dr. Şafak BAYIR

Dr. Şirin KARADENIZ

Dr. Tolga GÜYER

Dr. Tolga KABACA

Dr. Ümmühan AVCI YÜCEL

Dr. Ünal ÇAKIROĞLU

Dr. Yasemin DEMIRARSLAN ÇEVIK

Dr. Yasemin GÜLBAHAR

GÜVEN

Dr. Yasemin Koçak USLUEL

Dr. Yavuz AKPINAR

Dr. Yusuf Ziya OLPAK

\section{İletişim Bilgileri / Contact Information}

Internet Adresi / Web: http://dergipark.ulakbim.gov.tr/etku/

E-Posta / E-Mail: tguyer@gmail.com

Telefon / Phone: +90 (312) 2021738

Belgegeçer / Fax: +90 (312) 2028387

Adres / Adress: Gazi Üniversitesi, Gazi Eğitim Fakültesi, Bilgisayar ve Öğretim Teknolojileri Eğitimi Bölümü, 06500 Teknikokullar - Ankara / Türkiye 


\author{
Makale Geçmişi / Article History \\ Alınd1/Received: 31.10 .2015 \\ Düzeltme Alınd1/Received in revised form: 21.12.2015 \\ Kabul edildi/Accepted: 21.12.2015
}

\title{
MOBiL ÖĞRENMEYE YÖNELiK TUTUM ÖLÇEĞi GELIŞTiRME ÇALIŞMASı*
}

\author{
Kadir Demir ${ }^{1}$, Ercan Akpınar ${ }^{2}$
}

Öz

$\mathrm{Bu}$ çalışma, mobil öğrenmeye yönelik tutum ölçeği geliştirmek amacı ile gerçekleştirilmiştir. Ölçeğin geliştirilme sürecinde öncelikle literatür taraması yapılmıştır. Daha sonra mobil öğrenme hakkında 78 öğrenciye 7 adet açık uçlu soru sorulmuştur. Elde edilen veriler ve uzman görüşlerinden yararlanılarak 57 maddelik madde havuzu oluşturulmuştur. Kapsam geçerliliğini sağlamak amacıyla uzman görüşlerine başvurulmuştur. Uzmanların görüş ve önerileri doğrultusunda düzeltmeler yapılmıştır. Tutum maddesi olmayan maddeler ve birbirine benzer maddeler ölçekten çıkarılmıştır. Yapılan düzeltmelerden sonra madde havuzu 52 maddeye düşürülmüştür. Oluşturulan maddeler beşli likert tipinde olup, tamamen katılıyorum (5), katılıyorum (4), kısmen katılıyorum (3), katılmıyorum (2), tamamen katılmıyorum (1) şeklinde derecelendirilmiştir. Pilot uygulama, 2013-2014 güz yarıyılında Dokuz Eylül Üniversitesi Buca Eğitim Fakültesi ve Anadolu Üniversitesi Eğitim Fakültesi'nin farklı bölümlerinde öğrenim gören toplam 326 öğrenci ile gerçekleştirilmiştir. KMO değerini .936 olarak bulunmuştur. Faktör analizleri sonucunda 21 ölçek maddesinin 4 faktörde toplandığı ve ölçeğin toplam varyansın \% 51.116'sını açıkladığı belirlenmiştir. Ölçeğe madde yükü .40 'dan yüksek olan 45 madde dahil edilmiştir. Ölçeğin dört faktör ve 45 maddeden oluşan son halinde yer alan maddelerin yükleri .82 ile .40 arasında yer almaktadır. Ölçeğin son haline ait Cronbach Alfa güvenirlik katsayısı .950 hesaplanmış ve yüksek derecede güvenir olarak görülmüştür. Ölçekte yer alan tüm maddelerin alt üst grup ortalamalarına dayalı madde analizi sonuçları anlamlı derecede ayırt edici bulunmuştur $(p<.05)$. Bu araştırmanın lisans öğrencileri ile mobil öğrenme alanında yapılacak araştırmalara katkı sağlayacağı düşünülmektedir.

Anahtar Kelimeler: mobil öğrenme, tutum, ölçek geliştirme

Bu makale, birinci yazarın ikinci yazar danışmanlığında Dokuz Eylül Üniversitesi Eğitim Bilimleri Enstitüsü Bilgisayar ve Öğretim Teknolojileri Eğitimi Anabilim Dalı’nda 2014 yılında tamamladığı “Grafik ve Animasyon Dersindeki Mobil Öğrenme Uygulamalarının Öğrencilerin Akademik Başarılarına ve Mobil Öğrenmeye Yönelik Tutumlarına Etkisi" başlıklı Dokuz Eylül Üniversitesi Bilimsel Araştırma Projeleri Birimi tarafından 2013.KB.EGT.004 numarası altında desteklenen yüksek lisans tezinden üretilmiştir.

${ }^{1}$ Araş. Gör., Anadolu Üniversitesi, kadirdemir@anadolu.edu.tr

2 Prof. Dr., Dokuz Eylül Üniversitesi, ercan.akpinar@deu.edu.tr 


\title{
DEVELOPMENT OF ATTITUDE SCALE TOWARDS MOBILE LEARNING
}

\begin{abstract}
This present study was conducted with the purpose of developing an attitude scale towards mobile learning. Related literature was reviewed primarily in the process of developing the scale. Then by seven open-ended questions related with mobile learning were asked to 78 students. Taking the advantages of the data collected and the expert opinions, an item pool including 57 items was developed. In order to insure the content validity, the experts' opinions were used. In accordance with the recommendations and the opinions of the experts, the items were re-evaluated. The items which did not include attitude expression or which were alike were removed from the scale item pool. After making the revisions, the item pool included 52 items. These items created as five-point Likert-type and rated as totally agree (5), agree (4), partially agree (3), disagree (2), totally disagree (1). The pilot study was conducted with 326 undergraduate students, who studies in different departments in Dokuz Eylül University, Buca Faculty of Education and Anadolu University, Faculty of Education, in the first term of the 2013-2014 academic year. KMO value found as .936. 21 items of the scale grouped by four factors and explain the $\% 51.116$ of the total variance of the scale is determined in the result of factor analysis. 45 items which item load is higher than .40 were included to scale. The last version of the scale consists four factors and 45 items which loadings are between .82 and .40 . The Cronbach's alpha internal consistency coefficient which belongs the last version of the scale was computed as .950 and was seen as very highly reliable. The item analysis based on the difference between the upper and lower group results of the all items in the scale found significantly distinguished $(p<.05)$. This research is expected to contribute researchs which will be held in the field of mobile learning with undergraduate students.
\end{abstract}

Keywords: mobile learning, attitude, scale development

\section{Summary}

Habits of using emerging technologies are also rapidly change together the rapid development of technology. In parallel with the intensive use of mobile technologies in daily life, mobile learning contents are increasing day by day. This situation has facilitated student access to information via mobile devices and interact with information. The use of these technologies for educational purposes are supported by students. As a result, the concept of mobile learning has arisen.

There are several definitions of mobile learning in literature. According to the Wyne (2015), teaching and learning activities performed through devices such as wearable computers, tablet PC's, notebooks and smartphones are termed as mobile learning. According to the Walker (2007), mobile learning is not learning just using mobile devices, is learning between contexts. O'Malley et al. (2003) defined mobile learning as any kind of learning happens when the learner is not in predetermined place or learning when the 
learner transforms opportunities which mobile technology offers to the advantage. Trifonova ve Ronchetti (2003) defined mobile learning as e-learning performed via mobile devices that we can take with us every moment of daily life. Stone (2004) defined mobile learning as e-learning performed via devices which properties are small size, band width and network technology. Mobile learning, is not just delivering contents via devices, play a facilitator role in for learning occurs different time and context (Pachler, Cook, Bachmair ve Kress; 2010). There are many research towards how mobile devices and mobile learning applications effect academic achievement and attitude (Al-Fahad, 2009; Chen, 2013; Cheon ve ark., 2012; Ciampa, 2014; Jaradat, 2014; Kutluk ve Gülmez, 2014; Martin ve Ertzberger, 2013). It is stated when relevant researchs examined that efforts should be made devoted to student achievement, attitude and views about mobile learning (Jaradat, 2014; Martin ve Ertzberger, 2013; Özdamar Keskin, 2011). In this direction, this study was conducted with the purpose of reveal university students' views towards mobile learning. This research is expected to contribute researchs which will be held in the field of mobile learning with undergraduate students.

This present study was conducted with the purpose of developing an attitude scale towards mobile learning. Related literature was reviewed primarily in the process of developing the scale. Then by seven open-ended questions related with mobile learning were asked to 78 students. Taking the advantages of the data collected and the expert opinions, an item pool including 57 items was developed. In order to insure the content validity, the experts' opinions were used. In accordance with the recommendations and the opinions of the experts, the items were re-evaluated. The items which did not include attitude expression or which were alike were removed from the scale item pool. After making the revisions, the item pool included 52 items. These items created as five-point Likert-type and rated as totally agree (5), agree (4), partially agree (3), disagree (2), totally disagree (1). The pilot study was conducted with 326 undergraduate students, who studies in different departments in Dokuz Eylül University, Buca Faculty of Education and Anadolu University, Faculty of Education, in the first term of the 2013-2014 academic year. The zscore was used to identify outliers in the data set. Depending on the resuls of $Z$ points, 9 out of 326 participants participated in the research were defined as they had three standart deviation under; so that these people were expelled from the participants group. The analyses were carried on with 317 participants. In order to make the factor analysis feasible, Kaiser Meyer-Olkin (KMO) and Bartlett's sphericity test should be run. KMO value found as .936 after the result of the analysis. This value is considered as very good. Bartlett test was found significant $(\chi 2=8530.191 ; p<.000)$. The scale was judged as suitable for factor analysis. 21 items of the scale grouped by four factors and explain the \%51.116 of the total variance of the scale is determined in the result of factor analysis. 45 items which item load is higher than .40 were included to scale. The last version of the scale consists four factors and 45 items which loadings are between .82 and .40. The Cronbach's alpha internal consistency coefficient which belongs the last version of the scale was computed as .950 and was seen as very highly reliable. The item analysis based on the difference between the upper and lower group results of the all items in the scale found significantly distinguished $(p<.05)$.

It was seen that 20 items were located in the first factor and represented the satisfaction level towards mobile learning. While second factor consisted of 11 items representing the effect of mobile learning on learning, third factor included seven items and those items performed as the representatives of the motivation towards mobile learning. 
The last but not the least, seven items in the fourth factor were seen as the representatives of the usefulness of the mobile learning. Depending on the analyses, it can be said that the attitude scale towards mobile learning is valid and reliable.

The "Attitude Scale Towards Mobile Learning" can be used as a data collection tool in the studies which deal with mobile learning for undergraduate students. With the light of evolving technologies which are directly related to mobile learning such as wearables and Internet of things, the scale can be improved. With the help of this scale, the undergraduate students' attitudes towards mobile learning can be investigated before, during and after the upcoming researches. 


\section{Giriş}

Teknolojinin hızla gelişmesiyle birlikte bireylerin gelişen teknolojileri kullanma alışkanlıkları da hızlı bir değişim geçirmektedir. Bunlar arasında mobil teknolojiler ve bu teknolojilerin kullanımı önemli bir yer tutmaktadır. Mobil teknolojiler bilgiye erişme biçimlerimizi köklü bir şekilde değiştirip, belirli bir zamanda ve mekânda bilgiye erişim zorunluluğunu ortadan kaldırmaktadır. Kablosuz internete erişim ve mobil servis sağlayıcıların imkânlarının artmasıyla birlikte bireylerin her yerde ve her zaman bilgiye erişmeleri giderek yaygınlaşmaktadır. Bu yaygınlaşmanın en önemli sebepleri arasında mobil teknolojilerin iki temel özelliği olan taşınabilirlik ve kablosuz bağlantı olanağı gösterilmektedir (Georgiev, Georgieva ve Smrikarov, 2006). Mobil teknolojilerin günlük yaşamdaki bu denli yoğun kullanımına paralel olarak, mobil öğrenme içerikleri günden güne artış göstermektedir. Bu durum, öğrencilerin mobil cihazlarla bilgiye erişimini ve bilgiyle etkileşimini kolaylaştırarak öğrenciler tarafından bu teknolojilerin eğitim amaçlı kullanımını desteklemiştir. Bunun sonucu olarak mobil öğrenme kavramı ortaya çıkmıştır.

Mobil öğrenmenin alanyazında farklı tanımları bulunmaktadır. Wyne'e (2015) göre mobil öğrenme; giyilebilir bilgisayarlar, tablet bilgisayarlar, dizüstü bilgisayarlar ve akıllı telefonlar gibi cihazlar aracılığıla gerçekleştirilen öğretme ve öğrenme aktiviteleridir. Walker'a (2007) göre mobil öğrenme, sadece mobil cihazlar kullanılarak yapılan öğrenme değil, bağlamlar arası öğrenmedir. O’Malley ve ark. (2003) mobil öğrenmeyi, öğrenenin önceden belirlenmiş bir yerde olmadığı zamanda gerçekleşen herhangi bir çeşit öğrenme ya da öğrenenin mobil teknolojilerin sunduğu öğrenme fırsatlarını avantaja çevirebildiği zamanda gerçekleşen öğrenme olarak tanımlamaktadır. Trifonova ve Ronchetti (2003) mobil öğrenmeyi günlük hayatta her an yanımızda bulundurabileceğimiz taşınabilir cihazlar aracılığıyla yapılan e-öğrenme olarak tanımlamaktadır. Stone (2004) mobil öğrenmeyi boyutları küçük, bant genişliği ve ağ teknolojilerine sahip birçok özelliği barındıran cihazlarla yapılan e-öğrenme olarak tanımlamaktadır. Georgieva, Smrikarov ve Georgiev (2005) mobil öğrenmeyi öğrenme materyallerini sunabilecek ve öğretmen-öğrenci arasındaki etkileşimi her yerde, her zaman sağlayacak taşınabilir cihazların eğitimde kullanılması olarak açıklamaktadır. Farklı tanımlardan anlaşılacağı üzere mobil öğrenmeye ait tek ve kesin bir tanım bulunmamaktadır. Bazı araştırmacılar donanım özelliklerini ön plana çıkartırken, bazı araştırmacılar ise bağlamı ön plana çıkartmaktadır. Bu noktada mobil cihazların özelliklerinin her geçen gün gelişmesi ve değişmesinin, mobil öğrenmenin tanımının zaman içerisinde farklılaşmasına yol açtığı söylenebilir. Mobil öğrenme, sadece içeriklerin cihazlarla dağıtılması değil, öğrenmenin farklı zaman ve bağlamda gerçekleşmesi için mobil cihazların kolaylaştırıcı rolünü üstlenmesidir (Pachler ve diğ., 2010). Hızlı değişimler geçiren bu alanla ilgili araştırmacılar mobil öğrenmenin daha etkili hale nasıl getirilebileceğine yönelik araştırma yapmaya başlamışlardır. Bununla birlikte mobil öğrenmede kullanılan mobil cihazların eğitimi nasıl daha iyi hale getireceği de önemli bir araştırma konusu olarak yer almaktadır (Trifonova, 2003).

Mobil öğrenme sınıf içinde ve sınıf dışındaki öğrenme arasındaki bağlantıyı kurmaya fırsat tanımaktadır. Bu nedenle okulların öğrencilere mobil cihazlar sağlama veya sahip oldukları cihazlara uygun araçlar ve içerikler geliştirmesi zorunluluğu ortaya çıkmaktadır (Sharples, 2013). Çünkü kişisel ve bağlamsal teknolojiler yaşam boyu öğrenmeyi destekleyerek öğrenme deneyimini zenginleştirmektedir. Öğrenme süreçlerini zenginleştirmeyi amaçlayan yurt dışında yapılmış bir çok uygulamalı mobil öğrenme 
araştırması bulunmaktadır. Anderson ve ark. (2013) tarafından yapılan araştırmada öğrencilerin mobil cihazları iletişim kurmayı kolaylaştırıcı olarak gördükleri, işbirlikli olarak etkili çalışmalarını sağladığı görülmektedir. Evans'ın (2008) araştırmasında içerik sunma açısından mobil cihazların kitaplardan daha etkili olduğu sonucuna ulaştığı bilinmektedir. Martin ve Ertzberger (2013) tarafından yürütülen araştırmada mobil öğrenmenin öğrencilerin akademik başarısını ve derslere karşı olumlu tutumunu arttırdığı görülmektedir. Sharples'ın (2002) öğrencilerin mobil cihazları kullanmaları sayesinde öğrenmeleri üzerinde kontrol sahibi oldukları sonucuna ulaştığı görülmektedir. Sung ve Mayer (2013) araştırmalarında mobil öğrenme ile geleneksel öğrenme arasında bir fark olmadığı, bununla birlikte mobil öğrenmenin öğrenci motivasyonunu arttırdığı sonucuna ulaşmışlardır. Yang ve ark. (2013) tarafından yapılan araştırmada ise mobil öğrenmenin akademik başarıyı arttırdığı sonucuna ulaştıkları görülmektedir. (Anderson ve ark., 2013; Evans, 2008; Martin ve Ertzberger, 2013; Sharples, 2002; Sung ve Mayer, 2013; Yang ve ark., 2013).

Ülkemizde de araştırmacılar mobil öğrenme ile ilgili uygulamalı araştırmalar gerçekleştirmektedir. Çelik (2012) tarafından yapılan araştırmada mobil cihazların etkili ve verimli bir kullanım sunduğu ve öğrencilerin merak duygusunu uyandırdığı görülmektedir. Köse, Koç ve Yücesoy (2013) gerçekleştirdikleri araştırma sonucunda mobil öğrenmenin akademik başarıyı yükselttiği ve soyut ve teknik konularda öğrenmeyi daha basit ve eğlenceli hale getirdiğini ifade etmektedir. Ozan (2013) tarafından yürütülen araştırmada ise mobil öğrenmenin öğrencilerin kendilerini güvende hissetmelerini sağladığı ve öğrenmeyi daha kalıcı hale getirdiği görülmektedir. Özdamar Keskin'in (2011) akademisyenlerin mobil teknolojileri mesleki gelişim amaçlı kullanmaya olumlu baktıkları sonucuna ulaştığı görülmektedir. Sayın (2010) tarafından yürütülen araştırmada ise mobil öğrenme içeriklerinin çoklu ortam ögeleriyle desteklenmeleri gerektiği sonucuna ulaşıldığı görülmektedir. Sur'un (2011) araştırmasında mobil öğrenmenin akademik başarıyı arttırdığı ve öğrencilerin mobil öğrenmeye karşı olumlu tutum içerisinde oldukları sonucuna ulaştığı görülmektedir. Yıldırım (2012) ise öğrencilerin mobil eğitsel oyun oynamaya karşı olumlu tutum içerisinde oldukları sonucuna ulaştığını belirtmektedir. Ayrıca yapılan araştırmalarda mobil öğrenmenin derse karşı ilgi ve motivasyonu arttırdığı görülmektedir (Çelik, 2012; Köse, Koç ve Yücesoy, 2013; Oberer ve Erkollar, 2013; Ozan, 2013; Sur, 2011). Elde edilen olumsuz sonuçlar incelendiğinde mobil öğrenmede kullanılan mobil cihazların dikkat dağıtıcı unsurlar barındırdığı ve zaman zaman motivasyon kaybına sebep olduğu görülmektedir (Çelik, 2012; Ozan, 2013; Sur, 2011).

Mobil cihazlar yüksek işlem kapasiteleri ve her geçen gün gelişen yeni özellikleriyle birlikte büyük ilgi çekmektedir. Sosyal medya ve internet teknolojilerinde yaşanan gelişmeler mobil cihazları hayatımızın vazgeçilmez birer parçası yapmışlardır. Öğrencilerin de bu gelişmeleri yakından takip ettiği göz önünde bulundurularak, yurt içinde ve yurt dışında mobil cihazların ve mobil öğrenme uygulamalarının akademik başarıyı ve tutumu nasıl etkilediğine yönelik birçok araştırma yapılmaktadır (Al-Fahad, 2009; Chen, 2013; Cheon ve ark., 2012; Ciampa, 2014; Jaradat, 2014; Kutluk ve Gülmez, 2014; Martin ve Ertzberger, 2013). Ilgili araştırmalar incelendiğinde mobil öğrenme ile ilgili öğrenci başarı, tutum ve görüşlerine yönelik çalışmalar yapılması gerektiği belirtilmektedir (Jaradat, 2014; Martin ve Ertzberger, 2013; Özdamar Keskin, 2011). Yapılan araştırmalar incelendiğinde Al-Fahad (2009) tarafından lisans öğrencilerinin mobil öğrenmeye karşı tutum ve algılarının ölçülmesini amaçlayan araştırmada sekiz maddeden oluşan anket kullanılmıştır. 186 lisans öğrencisi ile yürütülen araştırma sonucunda öğrencilerin mobil öğrenmeye karşı anlamlı 
derecede olumlu tutum içerisinde oldukları sonucuna ulaşılmıştır. Chen (2013) araştırmasında lisans öğrencilerine dil öğretiminde tablet bilgisayarların etkisini araştırmıştır. Araştırmada veri toplama aracı olarak 30 soru ve 3 faktörden (kullanışlılık, etkililik, memnuniyet) oluşan yabancı dil ve tablet bilgisayar kullanımına yönelik maddeleri içeren ölçek kullanılmıştır. Öğrencilerin tablet bilgisayarların dil öğretiminde kullanılmasına yönelik anlamlı derecede olumlu tutumlar içerisinde oldukları sonucuna ulaşılmıştır. Cheon ve ark. (2012) tarafından yürütülen araştırmada ise kolej öğrencilerinin mobil öğrenmeye yönelik algıları araştırılmıştır. Veri toplama aracı olarak 30 madde ve 10 faktörden oluşan ölçek kullanılmıştır. Öğrencilerin mobil öğrenmeye yönelik anlamlı derecede olumlu tutum ve algıya sahip oldukları ulaşılan sonuçlar arasında yer almaktadır. Ciampa (2014) tarafından yürütülen araştırmada tablet bilgisayarların sınıf ortamında kullanımının 6 . sınıf öğrenci ve öğretmenlerinin deneyimleri üzerindeki etkileri araştırılmıştır. Veri toplama araçları olarak öğrenci ve öğretmenlerle yapılan görüşmeler ve öğretmen tarafından yazılan blog içeriği analiz edilmiştir. Araştırma sonucunda sınıf ortamında tablet bilgisayar kullanımın motivasyonu ve işbirliğini yükselttiği bununla birlikte dikkat dağıtıcı unsurlar barındırdığı sonuçlarına ulaşılmıştır. Jaradat (2014) tarafından gerçekleştirilen araştırmada ise lisans öğrencilerinin mobil öğrenmeye yönelik tutum ve algıları araştırılmıştır. Veri toplama aracı olarak üç sorudan oluşan anket kullanılmıştır. Öğrencilerin mobil öğrenmeyi geleneksel öğrenmeye tercih ettikleri ve mobil öğrenmeye karşı olumlu tutum içerisinde oldukları sonucuna ulaşılmıştır. Kutluk ve Gülmez (2014) ise yaptıkları araştırmada lisans öğrencilerinin mobil öğrenmeye yönelik bakış açılarını ortaya çıkartmayı amaçlamaktadır. Veri toplama aracı olarak 17 maddeden oluşan ölçek kullanılmıştır. Araştırma sonucunda öğrencilerin mobil öğrenmeye yönelik olumlu tutumlara sahip olduğu görülmektedir. Martin ve Ertzberger (2013) lisans öğrencileri ile yürüttükleri araştırmada ise mobil öğrenmenin akademik başarı ve tutuma etkisini araştırmışlardır. Veri toplama aracı olarak 10 maddeden oluşan ölçek kullanılmıştır. Araştırma sonucunda mobil öğrenmenin öğrencilerin akademik başarısını ve derslere karşı olumlu tutumunu arttırdığı görülmektedir.

Mobil öğrenme çalışmaları incelendiğinde lisans öğrencilerinin mobil öğrenmeye yönelik tutumlarını ölçmeyi amaçlayan, mobil öğrenmenin motivasyon, memnuniyet, kullanışlılık ve öğrenmeye etkisini bir arada ölçebilen geniş kapsamlı bir ölçek bulunmamaktadır. Ülkemizde mobil teknoloji destekli öğrenme ortamlarına yönelik bazı çalışmalar son yıllarda önem kazanmış ve ulusal düzeyde projeler başlatılmıştır. Bunlardan en geniş kapsamlı olanı Fırsatları Artırma ve Teknolojiyi İyileştirme Hareketi (FATiH) projesidir. Milli Eğitim Bakanlığı tarafından yürütülen FATiH Projesi kapsamında okulöncesi, ilköğretim, ortaöğretim öğrencilerine ve öğretmenlerine tablet bilgisayar verilmesi ve bu şekilde bilişim teknolojileri destekli öğretimin gerçekleştirilmesi amaçlanmaktadır (Milli Eğitim Bakanlığı, 2013). Bütün bu gelişmeler dikkate alındığında ve okul ortamında mobil öğrenmeyi kullanabilecekleri göz önünde bulundurulduğunda mevcut öğretmenlerin ve öğretmen adaylarının mobil öğrenmeye yönelik tutumlarının belirlenmesi önemli görülmektedir. Yakın gelecekte lisans öğrencilerinin öğretmen olacağı düşünüldüğünde yapılan çalışmanın FATiH projesine de katkısı olacağı beklenmektedir. Mobil teknolojilerin eğitim ortamlarına her geçen gün daha fazla entegre olması ve talep görmesi ile birlikte bu teknolojiler aracılığıyla gerçekleştirilen öğrenmeye yönelik öğrencilerin tutumlarını belirlemek ayrıca önemli görülmektedir. Özellikle lisans öğrencilerine yönelik yapılacak mobil öğrenmeye yönelik tutum çalışmaları önemli görülmektedir. Bu doğrultuda lisans öğrencilerinin mobil öğrenmeye yönelik tutumlarını ortaya çıkartmak amacıyla ölçek 
geliştirme ihtiyacı doğmuştur. Bu kapsamda önemli görülen bu araştırmada lisans öğrencilerinin mobil öğrenmeye yönelik tutumlarını ölçme amacıyla ölçek geliştirme amaçlanmaktadır. Bu araştırmanın ülkemizde lisans düzeyinde mobil öğrenme alanında yapılan uygulamalı çalışmalara ve gelecekte yapılacak araştırmalara katkı sağlayacağı düşünülmektedir.

\section{Yöntem}

\section{Çalışma Grubu}

Ölçek verileri, 2013-2014 güz yarıyılında Dokuz Eylül Üniversitesi Buca Eğitim Fakültesi ve Anadolu Üniversitesi Eğitim Fakültesi'nin farklı bölümlerinde öğrenim gören ve mobil öğrenme deneyimi olmayan toplam 326 lisans öğrencisinden toplanmıştır. Araştırmaya katılan 326 kişiden, eksik veri girişi yaptığı tespit edilen kişiler çıkartıldıktan sonra 317 kişi ile analizlere devam edilmiştir. Faktör analizinin gerçekleştirilebilmesi için örneklem sayısı olarak 200 orta, 300 iyi, 500 ise çok iyi olarak kabul edilmektedir (DeVellis, 2014; Tavşancıl, 2006). Çalışma grubunda yer alan kişi sayısı, faktör analizinin gerçekleştirilebilmesi için yeterli örneklem büyüklüğünü iyi derecede karşılamaktadır.

\section{Ölçme Aracı}

Ölçek geliştirme sürecinde ilk olarak mobil öğrenme özellikleri, mobil öğrenmeye karşı tutum ölçekleri ve mobil öğrenmeye karşı tutum odaklı bir literatür taraması gerçekleştirilmiştir. Alan uzmanlarının görüşü alınarak hazırlanan yedi adet açık uçlu sorudan oluşan görüş alma formu hazırlanmıştır. Görüş alma formu ile Dokuz Eylül Üniversitesi Buca Eğitim Fakültesi Bilgisayar ve Öğretim Teknolojileri Öğretmenliği Bölümü’nde öğrenim görmekte olan ve örneklemdeki kişileri temsil eden 78 lisans öğrencisinden bilgi toplanmıştır. Bu görüş alma formu ile öğrencilerden mobil öğrenmeye yönelik tutum konusuyla ilgili duygu, düşünce ve davranışlarını ifade etmeleri beklenmiştir. Öğrencilerden toplanan veriler analiz edilerek tutum ifadeleri ortaya çıkartılmıştır. Bu noktada 57 adet tutum ifadesi içeren taslak ölçek oluşturulmuştur.

Taslak halindeki ölçek uzman görüşlerine başvurulması amacıyla çeşitli üniversitelerde alan uzmanı olarak görev yapan öğretim elemanlarına gönderilmiştir. Uzmanların görüş ve önerileri doğrultusunda tutum maddesi olmayan maddeler ve birbirine benzer maddeler ölçekten çıkarılmıştır. Yapılan düzeltmelerden sonra ölçeğin son hali 41 olumlu ve 11 olumsuz olmak üzere toplam 52 maddeden oluşmuştur. Likert tipi ölçek, çeşitli duyuşsal özelliklerin yüksek güvenirlik ve geçerlik sağlanarak ölçülmesinde sıklıkla başvurulan bir yöntemdir (Tekindal, 2009). Bununla birlikte likert tipi ölçek uygulanan kişi, bir tutuma ilişkin katılma derecesi hakkında bilgi vermektedir (Tavşancıl, 2006). Oluşturulan maddeler beşli likert tipinde olup, tamamen katılıyorum (5), katılıyorum (4), kısmen katılıyorum (3), katılmıyorum (2), tamamen katılmıyorum (1) şeklinde derecelendirilmiştir. Faktör analizi, madde analizi, alt üst grup ortalamalarına dayalı madde analizi, iç tutarlılık katsayısı ve faktörler arası korelasyon katsayıları incelendikten sonra ölçeğe son hali verilmiştir. Ölçeğin dört faktör ve 45 maddeden oluşan son halinde yer alan maddelerin yükleri .82 ile .40 arasında yer almaktadır. Her bir maddeden alınan puanlar toplanarak ölçek toplam puanları hesaplanmıştır. Olumlu tutuma sahip bir kişi ölçekten en fazla 225 puan alabilmekte iken, ölçekten alınabilecek en düşük puan 45 olarak belirlenmiştir. 


\section{Verilerin Toplanması}

Geliştirilmek istenen mobil öğrenmeye yönelik tutum ölçeğine ait değişkenler arasındaki ortak özellikleri belirlemek, yapı geçerliğine ait kanıtlar elde etmek ve faktör yapısını belirlemek amacıyla açımlayıcı faktör analizi kullanılmıştır (Cohen, Manion ve Morrison, 2007; Çokluk, Şekercioğlu ve Büyüköztürk, 2010). Açımlayıcı faktör analizi araştırmacılar tarafından ölçülmek istenen faktörler hakkında derinlemesine bilgi elde edilmeye çalışılan analiz türüdür (Tavşancıl, 2006).

Veri seti içerisinde yer alan uç değerleri tespit etmek için, ölçek puanına ilişkin zpuanından yararlanılmıştır. Z puanları sonucuna göre araştırmaya katılan 326 kişiden 9'unun, üç standart sapma altında kaldığı görülmüş ve bu kişiler çalışmadan çıkartılmıştır. Analizlere 317 kişi ile devam edilmiştir.

Madde toplam puanlarına ilişkin betimsel istatistikler, verilerin normal dağılıma uygun olduğunu göstermektedir (Tablo 1). Elde edilen bu değerler, verilerin normal dağılıma uygun olduğunu göstermektedir.

Tablo 1: Ölçek Ham Puanlarına Ait Betimsel İstatistikler

\begin{tabular}{ll}
\hline Ortalama & 187.45 \\
Ortanca & 189.00 \\
Mode & 191 \\
Varyans & 690.62 \\
Standart Kayma & 26.28 \\
En küçük puan & 120 \\
En yüksek puan & 246 \\
Ranj & 126 \\
Çarpıklık & -.157 \\
Sivrilik & -.228 \\
\hline
\end{tabular}

\section{Bulgular}

\section{Açımlayıcı Faktör Analizi}

Mobil öğrenmeye yönelik tutum ölçeği açımlayıcı faktör analizi ile incelenmiştir. Açımlayıcı faktör analizi kullanılarak ölçeğin yapı geçerliğine ait kanıtlar elde edilmeye çalışılmış ve faktör yapısı belirlenmiştir. Ayrıca belirlenen faktör yapısı hakkında derinlemesine bilgi elde edilmiştir.

Ölçeğin 52 maddelik taslak halinin Cronbach Alfa güvenirlik katsayısı .949 olarak hesaplanmıştır. Doğrulanmış toplam madde korelasyonları .40 altında bulunan 3. madde (.275), 30. madde (.171), 37. madde (.069) ve 38. madde (.101) ölçekten çıkartıldıktan sonra tekrar hesaplanan Cronbach Alfa güvenirlik katsayısı .954 olarak hesaplanmıştır.

Faktör analizi yapılabilmesi için Kaiser Meyer-Olkin (KMO) ve Bartlett küresellik testi yapılması gerekmektedir. Yapılan analizler sonucunda KMO değeri .935 bulunmuştur. Bu değer çok iyi olarak kabul edilmektedir. Bartlett testi ise anlamlı bulunmuştur ( $\chi 2=8530.191$; 
$p<.000)$. Elde edilen bu veriler ışığında ölçeğin faktör analizine uygun olduğuna karar verilmiştir. Faktör analizi uygulanmış ve faktör özdeğerleri hesaplanmıştır (Tablo 2).

Tablo 2: Ölçeğe Ait Birinci Faktör Analizi Sonuçları

\begin{tabular}{lccc}
\hline Faktörler & Faktör Özdeğerleri & Açıklanan Varyans \% & Kümülatif Varyans \% \\
\hline 1 & 16.625 & 34.635 & 34.635 \\
2 & 2.954 & 6.155 & 40.789 \\
3 & 2.873 & 5.985 & 46.774 \\
4 & 1.870 & 3.896 & 50.671 \\
5 & 1.431 & 2.982 & 53.652 \\
6 & 1.330 & 2.771 & 56.424 \\
7 & 1.163 & 2.423 & 58.847 \\
8 & 1.055 & 2.198 & 61.045 \\
9 & 1.050 & 2.188 & 63.232 \\
10 & 1.000 & 2.084 & 65.316 \\
\hline
\end{tabular}

Birinci faktör analizinden elde edilen verilere göre özdeğeri 1.00'in üzerinde yer alan 10 faktör altında ölçek puanlarındaki varyansın \%65.316'sı açıklanmaktadır.

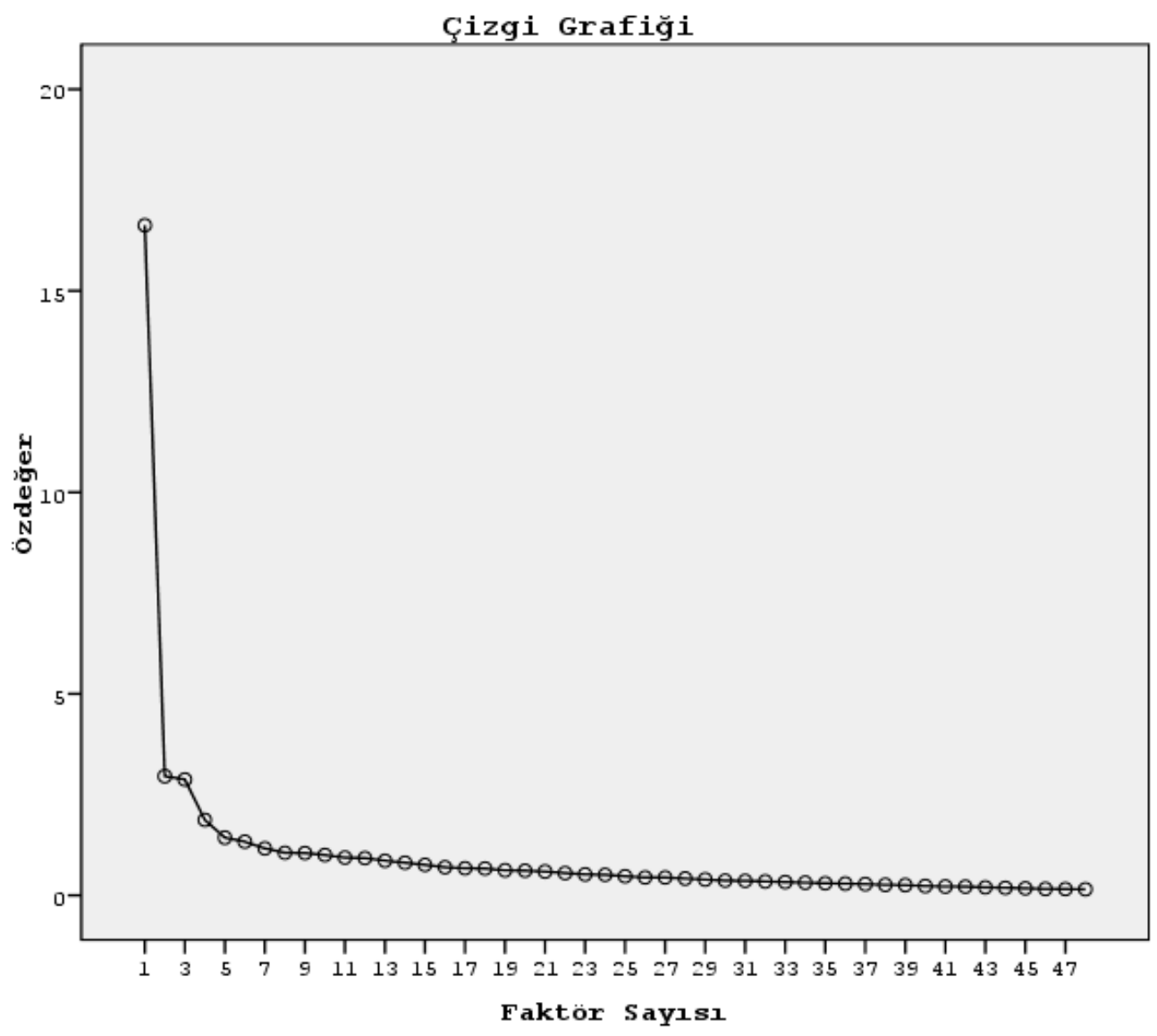

Şekil 1: Açımlayıcı Faktör Analizine Ait Yamaç Birikinti Grafiği 
Birinci faktör analizinden elde edilen açıklanan varyans verileri ve yamaç birikinti grafiği (scree plot) incelenmiştir. Bir ölçekte yer alan faktör sayısını faktör özdeğerleri incelenerek belirlenmektedir. Bu işlemden sonra yamaç birikinti grafiği incelenerek baskın faktör sayısını ortaya çıkartmak amaçlanmaktadır (Çokluk, Şekercioğlu ve Büyüköztürk, 2010). Yamaç birikinti grafiği incelendikten sonra ölçeğin 4 faktör altında toplandığı görüldüğü için elde kalan 48 madde 4 faktöre sınırlandırılarak tekrar analiz edilmiştir (Şekil 1). Sınırladıktan sonra yapılan faktör analizine bakınca iki faktörde farkı .10'dan az olan 17. madde ile 50. madde ve iki faktörde de yüksek değer alan 13. madde ölçekten çıkartılmıştır.

Tablo 3: Üçüncü Faktör Analizi Sonuçlarına Ait Varyans Değerleri

\begin{tabular}{lccc}
\hline Faktörler & Faktör Özdeğerleri & Açıklanan Varyans \% & Kümülatif Varyans \% \\
\hline 1 & 15.130 & 33.622 & 33.622 \\
2 & 2.921 & 6.492 & 40.114 \\
3 & 2.816 & 6.257 & 46.371 \\
4 & 1.787 & 3.971 & 50.341 \\
\hline
\end{tabular}

Problemli maddeler çıkartıldıktan sonra üçüncü kez faktör analizi yapılmıştır. Üçüncü faktör analizi ile ölçeğin son haline karar verilmiştir. Ölçek 45 maddeden oluşmaktadır. Ölçeğin son halinin Cronbach Alfa güvenirlik katsayısı .950 olarak hesaplanmıştır. Yapılan analizler sonucunda KMO değeri .931 bulunmuştur. Bu değer çok iyi olarak kabul edilmektedir. Bartlett testi ise anlamlı bulunmuştur $(\chi 2=7820.100 ; p<.000)$. Üçüncü faktör analizinden elde edilen verilere göre 4 faktör altında 45 maddeden oluşmaktadır ve bu 4 faktör ölçek puanlarındaki varyansın \%50.341'ini açıklamaktadır (Tablo 3). Ölçeğin son hali üzerinden bir öğrenci en düşük 45 en fazla 225 puan alabilmektedir. 45 maddeden oluşan ölçeğin son halinde yer alan maddelerin faktörlere göre dağılımları ve faktör yük değerleri belirlenmiştir (Tablo 4).

Tablo 4: Maddelerin Faktörlere Göre Dağılımları ve Faktör Yük Değerleri

\begin{tabular}{|c|c|c|c|c|c|c|c|}
\hline Madde & Faktör 1 & Madde & Faktör 2 & Madde & Faktör 3 & Madde & Faktör 4 \\
\hline m49 & .819 & m8 & .750 & $\mathrm{~m} 21$ & .752 & $\mathrm{~m} 46$ & .716 \\
\hline m47 & .757 & m11 & .732 & $\mathrm{~m} 20$ & .747 & $\mathrm{~m} 42$ & .693 \\
\hline m51 & .750 & $\mathrm{~m} 9$ & .731 & $\mathrm{~m} 18$ & .742 & m31 & .680 \\
\hline $\mathrm{m} 48$ & .747 & $\mathrm{~m} 12$ & .717 & m15 & .655 & m34 & .673 \\
\hline $\mathrm{m} 24$ & .712 & $\mathrm{~m} 7$ & .692 & m19 & .580 & m32 & .575 \\
\hline m45 & .687 & m5 & .680 & $\mathrm{~m} 16$ & .571 & m36 & .574 \\
\hline $\mathrm{m} 26$ & .672 & $\mathrm{~m} 4$ & .568 & $\mathrm{~m} 22$ & .542 & $\mathrm{~m} 6$ & .528 \\
\hline m44 & .668 & $\mathrm{~m} 10$ & .566 & & & & \\
\hline m41 & .647 & $\mathrm{~m} 1$ & .521 & & & & \\
\hline $\mathrm{m} 23$ & .645 & $\mathrm{~m} 2$ & .504 & & & & \\
\hline $\mathrm{m} 29$ & .626 & m14 & .414 & & & & \\
\hline $\mathrm{m} 28$ & .598 & & & & & & \\
\hline $\mathrm{m} 27$ & .561 & & & & & & \\
\hline m52 & .561 & & & & & & \\
\hline $\mathrm{m} 43$ & .557 & & & & & & \\
\hline m39 & .553 & & & & & & \\
\hline m33 & .494 & & & & & & \\
\hline
\end{tabular}




\begin{tabular}{ll}
$\mathrm{m} 40$ & .454 \\
$\mathrm{~m} 25$ & .437 \\
$\mathrm{~m} 35$ & .401 \\
\hline
\end{tabular}

\section{Faktörlerin Yorumlanması ve Faktör İsimlendirme}

Faktör analizi sonucunda, faktörler altında toplanan maddeler göz önünde bulundurularak faktörlere uygun birer isim bulmak veya faktörleri etiketlemek ölçek hakkında yorum yapmayı kolaylaştırmaktadır. Faktörlere isim verirken, faktörler altında bir araya gelen maddelerin ortak özelliğini belirlemek yardımcı olmaktadır (Çokluk, Şekercioğlu ve Büyüköztürk, 2010). Bu noktada mobil öğrenmeye yönelik tutum ölçeğine uygulanan faktör analizi sonuçları incelenmiştir. Ortaya çıkan dört faktör altında toplanan maddeler analiz edilmiştir. Mobil öğrenme ile ilgili geliştirilen ölçekler ve literatür tekrar gözden geçirilmiştir (Chen ve Huang, 2012; Chen, 2013; Cheon, Lee, Crooks ve Song, 2012; Wang, Wu ve Wang, 2009). Geçerliği ve güvenirliği sağlanmış olan mobil öğrenmeye yönelik tutum ölçeğine ait faktörlere ilgili literatür de dikkate alınarak uygun isimler verilmiştir (Tablo 8).

Tablo 5: Faktör İsimleri

\begin{tabular}{cccc}
\hline Faktör 1 & Faktör 2 & Faktör 3 & Faktör 4 \\
\hline Memnuniyet & Öğrenmeye Etki & Motivasyon & Kullanışlılık \\
\hline
\end{tabular}

\section{Alt Grup - Üst Grup Ortalamalarına Göre Madde Analizi}

Ölçekten alınan puanlara göre, en yüksek puandan en düşük puana doğru sıralama yapıldığında, sıralamanın her iki ucundan alınan \%27'lik grupların her bir maddeye verdikleri puan ortalamalarının karşılaştırılması madde analizidir (Tavşancıl, 2006). Bu analizde alt ve üst gruplar birbirinden bağımsız oldukları için bağımsız gruplar t-testi kullanılmıştır. Maddelerin alt ve üst gruplardaki ortalamalarına ilişkin t-testi sonuçları belirlenmiştir (Tablo 5). Bu veriler ölçekte yer alan bütün maddelerin anlamlı derecede ayırt ediciliğe sahip olduğunu göstermektedir.

Tablo 6: Tutum Ölçeği Alt ve Üst Grupların Ortalamaları

\begin{tabular}{|c|c|c|c|c|c|c|}
\hline \multirow{2}{*}{$\begin{array}{c}\text { Mobil Öğrenmeye Yönelik Tutum } \\
\text { Maddeleri }\end{array}$} & \multicolumn{2}{|c|}{ Alt Grup } & \multicolumn{2}{|c|}{ Üst Grup } & \multirow{2}{*}{$\mathrm{t}$} & \multirow{2}{*}{$\mathrm{p}$} \\
\hline & Ortalama & SS & Ortalama & SS & & \\
\hline \multicolumn{7}{|l|}{ Faktör 1: Memnuniyet Faktörü } \\
\hline $\begin{array}{l}\text { M49. Derslerim mobil öğrenme ile } \\
\text { işlenirse daha çok benimserim. }\end{array}$ & 2.45 & .82 & 4.25 & .77 & -16.07 & .000 \\
\hline $\begin{array}{l}\text { M47. Mobil öğrenme ile işlenen } \\
\text { derslerden daha çok verim alırım. }\end{array}$ & 2.58 & .78 & 4.13 & .78 & -13.06 & .000 \\
\hline $\begin{array}{l}\text { M51. Mobil teknolojiler yardımıyla } \\
\text { yapılan dersler ilgimi çeker. }\end{array}$ & 2.76 & .70 & 4.47 & .68 & -17.03 & .000 \\
\hline $\begin{array}{l}\text { M48. Mobil cihazların derslerde } \\
\text { kullanılmasını öneririm. }\end{array}$ & 2.66 & .85 & 4.49 & .63 & -15.23 & .000 \\
\hline
\end{tabular}


M24. Bütün derslerim mobil öğrenme ile işlenirse öğrenmeye olan ilgim artar.

M45. Derslerimde mobil cihazların

kullanılması kazanımlarımı arttırır.

M26. Derslerimde mobil cihazları

kullanmak beni mutlu eder.

M44. Mobil öğrenme yöntemi daha hızlı öğrenmemi sağlar.

M41. Mobil cihazlar üzerinden

bildirimler almak derse karşı

güdülenmemi sağlar.

M23. Mobil öğrenmeyi bütün

derslerimde kullanmak isterim.

M29. Mobil öğrenme uygulamaları

dersin kalitesini arttırır.

M28. Mobil cihazlarda yer alan çoklu

ortam özellikleri derse olan ilgimi

arttırır.

M27. Mobil cihazlar geri bildirim almamı

kolaylaştırır.

M52. Derslerimde mobil cihazları

kullanmak kolaydır.

M43. Mobil cihazları derslerimde

kullanmak öğrenmem üzerinde kontrol

sahibi olmamı sağlar.

M39. Mobil öğrenmede kullanılan

zenginleştirilmiş ders içerikleri derse ilgi

duymamı sağlar.

M33. Mobil öğrenme derste öğrendiğim

bilgileri pekiştirmemde yararlıdır.

M40. Mobil öğrenme uygulamaları ile

nasıl öğreneceğime kendim karar

veririm.

M25. Derslerimde mobil cihazları

kullanacak yeterli bilgiye sahibim.

M35. Mobil cihazlar ile grup çalışmaları

daha verimli olur. $\begin{array}{llllll}2.44 & .94 & 4.05 & .86 & -13.61 & .000\end{array}$

$\begin{array}{llllll}2.94 & .76 & 4.33 & .61 & -13.81 & .000\end{array}$

$\begin{array}{llllll}2.88 & .82 & 4.50 & .65 & -15.95 & .000\end{array}$

$\begin{array}{llllll}2.81 & .87 & 4.35 & .57 & -13.08 & .000\end{array}$

$\begin{array}{llllll}2.75 & .82 & 4.32 & .73 & -13.03 & .000\end{array}$

$\begin{array}{llllll}2.75 & .96 & 4.44 & .76 & -14.63 & .000\end{array}$

$\begin{array}{llllll}2.92 & .85 & 4.50 & .59 & -15.75 & .000\end{array}$

$\begin{array}{llllll}2.81 & .85 & 4.52 & .63 & -16.57 & .000\end{array}$

$\begin{array}{llllll}3.33 & .78 & 4.61 & .54 & -14.08 & .000\end{array}$

$\begin{array}{llllll}3.16 & .72 & 4.31 & .83 & -9.53 & .000\end{array}$

$\begin{array}{llllll}2.96 & .87 & 4.22 & .72 & -10.13 & .000\end{array}$

$\begin{array}{llllll}2.90 & .85 & 4.33 & .59 & -14.40 & .000\end{array}$

$\begin{array}{llllll}3.13 & .77 & 4.34 & .61 & -13.20 & .000\end{array}$

$\begin{array}{llllll}3.11 & .83 & 4.33 & .66 & -12.12 & .000\end{array}$

$\begin{array}{llllll}3.21 & 1.06 & 4.34 & .81 & -7.46 & .000\end{array}$

$\begin{array}{llllll}2.86 & .91 & 3.94 & .89 & -7.72 & .000\end{array}$

Faktör 2: Öğrenmeye Etki Faktörü

M8. Mobil öğrenme güncel bilgiye

$\begin{array}{llllll}3.60 & 1.02 & 4.81 & .40 & -10.92 & .000\end{array}$

ulaşmamı sağlar.

$\begin{array}{lllllllll}\text { M11. Mobil öğrenme sayesinde bilgiye } & 3.39 & .91 & 4.68 & .68 & -11.68 & .000\end{array}$

her an ulaşırım.

$\begin{array}{lllllll}\text { M9. Mobil öğrenme zamandan tasarruf } & 3.42 & 1.06 & 4.79 & .47 & -11.91 & .000\end{array}$

etmemi sağlar.

M12. Mobil öğrenme sayesinde

$\begin{array}{llllll}3.40 & .88 & 4.78 & .45 & -13.35 & .000\end{array}$

istediğim ortamda (ulaşım. ev vb. )

öğrenmemi sağlarım. 
M7. Mobil cihazlar aracılığıyla ders

hakkında arkadaşlarımla anında iletişim

$\begin{array}{llllll}2.87 & .95 & 4.27 & .83 & -10.52 & .000\end{array}$

M4. Mobil cihazlar aracılığıyla

\subsection{7}

ödevlerimi daha kolay yaparım.

M10. Mobil öğrenme dersleri çevrimiçi

3.20

M1. Mobil cihazlar aracılığıyla ders

içeriklerine mekandan bağımsız olarak erişirim.

M2. Mobil cihazlar aracılığıyla ders

$\begin{array}{llllll}3.12 & .88 & 4.33 & .71 & -10.23 & .000\end{array}$
içeriklerine her zaman erişirim.

M14. Mobil öğrenme sosyal etkileşimi

$\begin{array}{llllll}3.24 & 1.02 & 4.52 & .73 & -10.10 & .000\end{array}$
arttırır.

\begin{tabular}{|c|c|c|c|c|c|c|}
\hline \multicolumn{7}{|l|}{ Faktör 3: Motivasyon Faktörü } \\
\hline $\begin{array}{l}\text { M21. Mobil öğrenme derse ilişkin } \\
\text { merakımı arttırır. }\end{array}$ & 2.86 & .80 & 4.21 & .79 & -11.83 & .000 \\
\hline $\begin{array}{l}\text { M20. Mobil öğrenme derse ilişkin } \\
\text { motivasyonumu arttırır. }\end{array}$ & 2.80 & .86 & 4.27 & .76 & -11.89 & .000 \\
\hline $\begin{array}{l}\text { M18. Mobil öğrenme derslere ilgimi } \\
\text { arttırır. }\end{array}$ & 2.75 & .86 & 4.25 & .90 & -11.37 & .000 \\
\hline $\begin{array}{l}\text { M15. Mobil öğrenme öğrendiğim } \\
\text { bilgilerin kalıcı olmasını sağlar. }\end{array}$ & 2.76 & .81 & 4.07 & .84 & -12.82 & .000 \\
\hline $\begin{array}{l}\text { M19. Mobil öğrenme dersi öğrenmem } \\
\text { açısından yararlıdır. }\end{array}$ & 2.94 & .76 & 4.46 & .59 & -15.64 & .000 \\
\hline $\begin{array}{l}\text { M16. Mobil öğrenme öğrenmemi } \\
\text { kolaylaştırır. }\end{array}$ & 3.00 & .76 & 4.45 & .66 & -17.47 & .000 \\
\hline $\begin{array}{l}\text { M22. Mobil öğrenme keşfetme } \\
\text { duygumu güdüler. }\end{array}$ & 3.01 & .79 & 4.33 & .89 & -11.11 & .000 \\
\hline \multicolumn{7}{|l|}{ Faktör 4: Kullanışlılık Faktörü } \\
\hline $\begin{array}{l}\text { M46. Mobil cihazları derslerimde } \\
\text { kullanırken zorluklar yaşarım. }\end{array}$ & 2.92 & .93 & 3.93 & 1.00 & -7.10 & .000 \\
\hline $\begin{array}{l}\text { M42. Derslerimde mobil öğrenme } \\
\text { desteği kullanılması beni kaygılandırır. }\end{array}$ & 2.98 & .79 & 3.82 & 1.04 & -6.03 & .000 \\
\hline $\begin{array}{l}\text { M31. Mobil öğrenme teknik sorunlar } \\
\text { yüzünden verimsizdir. }\end{array}$ & 2.60 & .84 & 3.30 & 1.00 & -4.43 & .000 \\
\hline $\begin{array}{l}\text { M34. Derslerin mobil öğrenme ile } \\
\text { işlenmesi beni endişelendirir. }\end{array}$ & 2.89 & .90 & 3.82 & 1.00 & -7.01 & .000 \\
\hline $\begin{array}{l}\text { M32. Mobil öğrenme internet bağlantısı } \\
\text { sorunları yüzünden verimsizdir. }\end{array}$ & 2.49 & .84 & 2.86 & .91 & -2.57 & .012 \\
\hline $\begin{array}{l}\text { M36. Mobil cihazların farklı işletim } \\
\text { sistemlerine sahip olması öğrenmeyi } \\
\text { olumsuz etkiler. }\end{array}$ & 2.80 & .88 & 3.27 & 1.06 & -3.23 & .002 \\
\hline $\begin{array}{l}\text { M6. Mobil cihazlar aracılığıyla ders } \\
\text { çalışmak dikkatimi dağıtır. }\end{array}$ & 2.64 & 1.18 & 3.74 & .95 & -6.30 & .000 \\
\hline
\end{tabular}




\section{Güvenirlik Analizi}

Ölçek güvenirliğini belirlemek için Cronbach Alfa kullanılmıştır. Cronbach Alfa derecelendirilmiş tutum ölçeklerinde kullanılan güvenirlik katsayılarından birisidir (Tavşancıl, 2006). Cronbach Alfa güvenirlik katsayısı değeri .90 üzerinde çok yüksek derecede güvenir, .90 ile . 80 arasında yüksek derecede güvenir, .79 ile .70 arasında güvenir olarak kabul edilmektedir (Cohen, Manion ve Morrison, 2007). Faktörler incelendiğinde her faktörün iç tutarlııı katsayısının güvenilir çıktığı görülmektedir (Tablo 6). Ayrıca ölçeğin 45 maddeden oluşan son halinin iç tutarlılık katsayısı .950 çok yüksek derecede güvenilir olarak bulunmuştur.

Tablo 7: Mobil Öğrenmeye Yönelik Tutum Ölçeği Cronbach Alfa ( $\alpha$ ) Güvenirlik Analizi Sonuçları

\begin{tabular}{lll}
\hline Faktör & Madde Sayısı & Cronbach's Alfa $(\alpha)$ \\
\hline Memnuniyet & 20 & .942 \\
Öğrenmeye Etki & 11 & .877 \\
Motivasyon & 7 & .886 \\
Kullanışlılık & 7 & .776 \\
Toplam & 45 & .950 \\
\hline
\end{tabular}

Faktörlerin birbirleriyle ve ölçek toplam puanları arasındaki ilişkiyi ortaya çıkartmak amacıyla Pearson Korelasyon katsayıları hesaplanmıştır (Tablo 7). Tabloda görülen Pearson Korelasyon katsayılarından anlaşıldığı üzere faktörlerin birbirleriyle ve ölçek toplam puanıyla aralarındaki ilişki, $\mathrm{p}<0.01$ düzeyinde anlamlı bulunmuştur.

Tablo 8: Faktör Toplam Puanları ve Ölçek Toplam Puanları Arasındaki İlişkilere Ait Pearson Korelasyon Katsayıları

\begin{tabular}{|c|c|c|c|c|c|}
\hline Faktör & Memnuniyet & Öğrenmeye Etki & Motivasyon & Kullanışlılık & Toplam Puan \\
\hline Memnuniyet & 1 & $.590(* *)$ & $.703(* *)$ & $.293(* *)$ & $.924(* *)$ \\
\hline Öğrenmeye Etki & $.590(* *)$ & 1 & $.566(* *)$ & $.261(* *)$ & $.790\left(^{* *}\right)$ \\
\hline Motivasyon & $.703(* *)$ & $.566(* *)$ & 1 & $.227(* *)$ & $.808(* *)$ \\
\hline Kullanışlılık & $.293(* *)$ & $.261(* *)$ & $.227(* *)$ & 1 & $.476(* *)$ \\
\hline Toplam Puan & $.924(* *)$ & $.790(* *)$ & $.808(* *)$ & $.476(* *)$ & 1 \\
\hline
\end{tabular}

Anlamlılık Düzeyi $p<0.01$ 


\section{Sonuçlar}

$\mathrm{Bu}$ çalışmada mobil öğrenmeye yönelik tutum ölçeği geliştirmek amaçlanmıştır. Ölçeğin 52 maddelik taslak hali 326 lisans öğrencisine uygulanmıştır. Elde edilen veriler faktör analizi uygulanması için uygun bulunmuştur. Ayrıca madde analizi, alt üst grup ortalamalarına dayalı madde analizi, iç tutarlılık katsayısı ve faktörler arası korelasyon katsayıları incelenmiştir. Ölçeğe madde yükü .40'dan yüksek olan 45 madde dahil edilmiştir. Açımlayıcı faktör analizi sonucunda geliştirilen mobil öğrenmeye yönelik tutum ölçeğinde dört faktörlü bir yapı gözlenmiştir. Ölçeğin dört faktör ve 45 maddeden oluşan son halinde yer alan maddelerin yükleri .82 ile .40 arasında yer almaktadır. Ölçeğin son haline ait Cronbach Alfa güvenirlik katsayısı .950 olarak hesaplanmıştır. Ölçekte yer alan tüm maddelerin alt üst grup ortalamalarına dayalı madde analizi sonuçları anlamlı derecede ayırt edici bulunmuştur $(p<.05)$.

Ölçekte yer alan faktörler memnuniyet, öğrenmeye etki, motivasyon ve kullanışlılık olarak adlandırılmıştır. Memnuniyet faktörü altında yer alan 20 maddenin mobil öğrenmeye yönelik öğrenci memnuniyetini temsil ettiği görülmektedir. Öğrenmeye etki faktörü altında 11 madde yer almakta ve bu maddeler mobil öğrenmenin öğrenmeye etkisini irdelemektedir. Motivasyon faktörü altında 7 madde yer almakta ve bu maddeler öğrencilerin mobil öğrenmeye yönelik motivasyonlarını ölçmeyi amaçlamaktadır. Kullanışlıık faktörü altında yer alan 7 maddede ise mobil öğrenmede kullanılan mobil cihazların öğrenciler açısından kullanışııı̆̆ı temsil edilmektedir. Alanyazında mobil öğrenmenin öğrenci memnuniyetini arttırdığı (Köse, Koç ve Yücesoy, 2013; Martin ve Ertzberger, 2013; Sur, 2011; Yıldırım, 2012), öğrenmeye etki ettiği (Anderson ve ark., 2013; Evans, 2008; Ozan, 2013;Yang ve ark., 2013), motivasyonu arttırdığı (Çelik, 2012; Oberer ve Erkollar, 2013; Sung ve Mayer, 2013) ifade edilmektedir. Bununla birlikte mobil öğrenmede kullanılan mobil cihazların öğrenciler açısından kullanışlı olduğuna yönelik bulgular da mevcuttur (Çelik, 2012; Köse, Koç ve Yücesoy, 2013). Elde edilen dört faktöre ait iç tutarlılık katsayılarının .70'in üzerinde olduğu ve bu faktörlerin kendi içerisinde tutarlı ölçme yaptıkları görülmektedir. Bu çalışma sonunda mobil öğrenmeye yönelik tutum ölçeği geçerli ve güvenilir olarak geliştirilmiştir.

Alanyazında mobil öğrenmeye yönelik tutumu farklı boyutlarda ele alan çalışmalar yer almaktadır (Al-Fahad, 2009; Chen, 2013; Cheon ve ark., 2012; Martin ve Ertzberger, 2013). Bu çalışmalar incelendiğinde Al-Fahad (2009) tarafından geliştirilen ölçekte tutum ve algı olarak iki boyutta; Chen (2013) tarafından kullanışlılık, etkililik ve memnuniyet olarak üç boyutta; Cheon ve ark. (2012) tarafından öğretmen hazır bulunuşluğu, öğrenci hazır bulunuşluğu, tutum, kullanışııık, kullanım kolaylığı, öznel norm, öz yeterlik, öğrenme özerkliği, davranışsal kontrol ve niyet olarak on boyutta; Martin ve Ertzberger (2013) tarafından ise akademik başarı ve tutum olarak iki boyutta ele alındığı görülmektedir. Bu çalışmalarda memnuniyet, öğrenmeye etki, motivasyon ve kullanışlılık faktörlerinin bir arada olduğu bir ölçeğe rastlanmamaktadır. Bununla birlikte Chen (2013) ve Cheon ve ark. (2012) tarafından geliştirilen ölçeklerde yer alan memnuniyet ve kullanışlılık faktörleri ile bu çalışmada elde edilen faktörler arasında paralellik olduğu görülmektedir. 


\section{Öneriler}

Bu çalışmada, lisans öğrencilerinin mobil öğrenmeye yönelik tutumlarını ölçebilecek bir ölçek geliştirilmiştir. Çalışma kapsamında geliştirilen ölçek ile lisans öğrencilerinin mobil öğrenmeye yönelik tutumları araştırma öncesinde, sırasında ve sonrasında belirlenebilir. Bu ölçme aracı ile sadece öğrencilerin mobil öğrenmeye yönelik tutumları ortaya çıkartılabilir. $\mathrm{Bu}$ nedenle mobil öğrenmeye yönelik tutumlarını farklı verilerle ortaya çıkartmak ve desteklemek amacıyla görüşme gerçekleştirilmesi önerilmektedir. Geliştirilmiş olan bu ölçek ile farklı bölümlerde okuyan lisans öğrencilerinin mobil öğrenmeye yönelik tutumları belirlendikten sonra elde edilen bulguların karşılaştırılması önerilebilir. Ayrıca elde edilen bulgular ışığında mobil cihazlar aracılığıyla gerçekleştirilen eğitimde düzenlemeler ve iyileştirilmeler yapılabilir.

Mobil öğrenmeye yönelik tutum ölçeğinin farklı cihazların eğitimde kullanımını irdeleyen çalışmalara yardımcı olacağı düşünülmektedir. Geliştirilen tutum ölçeğinin mobil öğrenmeyi işe koşan uzaktan eğitim çalışmalarına katkı sağlayabileceği düşünülmektedir. Mobil öğrenmeye yönelik tutum ölçeği ile tüm lisans öğrencilerine yönelik tarama ve karşılaştırma çalışmaları gerçekleştirilebilir. Bu ölçek aracılığıyla farklı lisans bölümleri, cinsiyet ve farklı demografik özellikler gibi değişkenler açısından mobil öğrenmeye yönelik tutumun değişip değişmediği araştırılabilir. 


\section{Kaynakça}

Anderson, J., Franklin, T., Yinger, N., Sun, Y., ve Geist, E. (2013, Eylül). Going mobile: Lessons learned from introducing tablet PCs into the business classroom. The Clute Institute International Academic Conference' ta sunulmuştur. Las Vegas: Amerika Birleşik Devletleri.

Al-Fahad, F. N. (2009). Students' attitudes and perceptions towards the effectiveness of mobile learning in King Saud University, Saudi Arabia. Turkish Online Journal of Educational Technology, 8(2), 111-119.

Chen, C. C., ve Huang, T. C. (2012). Learning in a u-Museum: Developing a context-aware ubiquitous learning environment. Computers \& Education, 59(3), 873-883.

Chen, X. B. (2013). Tablets for informal language learning: Student usage and attitudes. Language, Learning \& Technology, 17(1), 20-36.

Cheon, J., Lee, S., Crooks, S. M. ve Song, J. (2012). An Investigation of mobile learning readiness in higher education based on the theory of planned behavior. Computers \& Education, 59(3), 1054-1064.

Ciampa, K. (2014). Learning in a mobile age: An investigation of student motivation. Journal of Computer Assisted Learning, 30(1), 82-96.

Cohen, L. Manion. L. ve Morrison, K.(2007). Research methods in education. New York: Routledge.

Çelik, A. (2012) Yabancı dil öğreniminde karekod destekli mobil öğrenme ortamının aktif sözcük öğrenimine etkisi ve öğrenci görüşleri: Mobil sözlük örneği. (Yayımlanmamış yüksek lisans tezi). Gazi Üniversitesi, Eğitim Bilimleri Enstitüsü, Ankara.

Çokluk, Ö., Şekercioğlu, G., ve Büyüköztürk, ş. (2010). Sosyal bilimler için çok değişkenli istatistik: SPSS ve LISREL uygulamaları. Ankara: Pegem Akademi.

DeVellis, R.F. (2014). Ölçek geliştirme kuram ve uygulamaları (Tarık Totan, Çev.). Ankara: Nobel Yayıncılık. (Orjinal baskı, 2011).

Evans, C. (2008). The effectiveness of m-learning in the form of podcast revision lectures in higher education. Computers \& Education, 50(2), 491-498.

Milli Eğitim Bakanlığı [MEB] (2013). Eğitimde FATiH Projesi. 28 Ağustos 2013 tarihinde http://fatihprojesi.meb.gov.tr/ adresinden erişilmiştir. 
Georgiev, T., Georgieva, E. ve Smrikarov, A. (2006). M-learning - A new stage of e-learning CompSysTech '04 Proceedings of the 5th International Conference on Computer Systems and Technologies, 1-5.

Georgieva, E., Smrikarov, A. ve Georgiev, T. (2005, Haziran). A general classification of mobile learning systems. International Conference on Computer Systems and Technologies'te sunulmuştur. Varna: Bulgaristan.

Jaradat, R. M. (2014). Students' attitudes and perceptions towards using m-learning for French language learning: A case study on Princess Nora University. International Journal of Learning Management Systems, 2(1), 33-44.

Köse, U., Koç, D. ve Yücesoy, S. A. (2013). An augmented reality based mobile software to support learning experiences in computer science courses. Procedia Computer Science, 25, 370-374.

Kutluk, F. A. ve Gülmez, M. (2014). A research about mobile learning perspectives of university students who have accounting lessons. Procedia-Social and Behavioral Sciences, 116, 291-297.

Martin, F. ve Ertzberger, J. (2013). Here and now mobile learning: An experimental study on the use of mobile technology. Computers \& Education, 68, 76-85.

Oberer, B. ve Erkollar, A. (2013). Mobile learning in higher education: A marketing course design project in Austria. Procedia-Social and Behavioral Sciences, 93, 2125-2129.

O’Malley, C., Vavoula, G., Glew, J., Taylor, J., Sharples, M. ve Lefrere, P. (2003) Guidelines for learning/teaching/tutoring in a mobile environment. Mobilearn Project deliverable. 28 Ağustos 2013 tarihinde http://www.mobilearn.org/download/results/guidelines.pdf adresinden erişilmiştir.

Ozan, O. (2013) Bağlantıcı mobil öğrenme ortamlarında yönlendirici destek. (Yayımlanmamış doktora tezi). Anadolu Üniversitesi, Sosyal Bilimler Enstitüsü, Eskişehir.

Özdamar Keskin, N., (2011). Akademisyenler için bir mobil öğrenme sisteminin geliştirilmesi ve sınanması. (Yayınlanmamış doktora tezi) Anadolu Üniversitesi, Eğitim Bilimleri Enstitüsü. Eskişehir.

Pachler, N., Cook, J., Bachmair, B. ve Kress, G. (Ed.). (2010). Mobile learning: Structures, agency, practices. Londra: Springer.

Sayın, Z. (2010) Mobil telefonlarla mobil öğrenme üzerine bir araştırma ve örnek uygulama (Yayımlanmamış yüksek lisans tezi). Selçuk Üniversitesi, Fen Bilimleri Enstitüsü, Konya. 
Sharples, M. (2002). Disruptive devices: Mobile technology for conversational learning. International Journal of Continuing Engineering Education and Life Long Learning, 12(5), 504-520.

Sharples, M. (2013). Mobile learning: research, practice and challenges. Distance Education in China, 3(5), 5-11.

Stone, A. (2004). Designing scalable, effective mobile learning for multiple technologies. J. Attwell ve C. Savill-Smith (Ed.), Learning with mobile devices içinde (ss. 145-153). Londra: Öğrenme ve Beceril Geliştirme Ajansı.

Sung, E. ve Mayer, R. E. (2013). Online multimedia learning with mobile devices and desktop computers: An experimental test of Clark's methods-not-media hypothesis. Computers in Human Behavior, 29(3), 639-647.

Sur, E. (2011) Mobil öğrenme ve web destekli öğrenme yöntemlerinin karşılaştırılması (Sinop Üniversitesi Gerze Meslek Yüksekokulu'nda bir uygulama). (Yayımlanmamış yüksek lisans tezi). Gazi Üniversitesi, Bilişim Enstitüsü, Ankara.

Tavşancıl, E. (2006). Tutumların ölçülmesi ve SPSS ile veri analizi. Ankara: Nobel.

Tekindal, S. (2009). Duyuşsal özelliklerin ölçülmesi için araç oluşturma. Ankara: Pegem Akademi.

Trifonova, A. (2003). Mobile learning-Review of the literature. (Rapor No: DIT-03-009). Trento Üniversitesi, Bilgi ve İletişim Teknolojileri Bölümü.

Trifonova, A. ve Ronchetti, M. (2003). Where is mobile learning going? World Conference on E-Learning in Corporate, Government, Healthcare, and Higher Education, 1, 17941801.

Walker, K. (2007). Introduction: Mapping the landscape of mobile learning. M. Sharples (Ed.), Big issue in mobile learning: A report of a new workshop by the Kaleidoscope Network of excellence mobile learning initiative içinde (ss. 5-6). Nottingham, Ingiltere: Nottingham Üniversitesi, Öğrenme Bilimi ve Araştırma Enstitüsü.

Wang, Y. S., Wu, M. C., ve Wang, H. Y. (2009). Investigating the determinants and age and gender differences in the acceptance of mobile learning. British Journal of Educational Technology, 40(1), 92-118.

Wyne, M. F. (2015, Haziran). Merging mobile learning into traditional education, 20132016. The International Conference on E-Learning in the Workplace'te sunulmuştur. New York: Amerika Birleşik Devletleri. 
Yang, G., Chen, N. S., Sutinen, E., Anderson, T. ve Wen, D. (2013). The effectiveness of automatic text summarization in mobile learning contexts. Computers \& Education, 68, 233-243.

Yıldırım, N. (2012) Yabancı dil eğitiminde eğitsel oyunlar aracılığıyla mobil öğrenme. (Yayımlanmamış yüksek lisans tezi). Fırat Üniversitesi, Eğitim Bilimleri Enstitüsü, Elazığ. 